\title{
ВНЕУЧЕБНАЯ ДЕЯТЕЛЬНОСТЬ КАК МЕХАНИЗМ АДАПТАЦИИ ИНОСТРАННЫХ СТУДЕНТОВ В РОССИЙСКИХ ВУЗАХ
}

\section{EXTRACURRICULAR ACTIVITIES AS A MECHANISM FOR ADAPTATION OF FOREIGN STUDENTS IN RUSSIAN UNIVERSITIES}

\section{Kochesokova \\ L. Abazova \\ Z. Dzhanhotova \\ Z. Gutaeva}

Summary: The article is devoted to the study of extracurricular activities as a mechanism for adaptation of foreign students in Russian universities. The author proved the relevance and significance of the topic of research. The need to organize extracurricular activities in educational organizations where foreign students are subjects of study is proved through the prism of the idea of humanization. The thesis is justified that extracurricular activity, as one of the manifestations of continuing education, within the framework of which the creation of a humanisticoriented environment is possible, is a direction capable of forming and preparing a foreign student for the further development of adaptive competence, including in the conditions of future professional activity.

Keywords: adaptation, maladaptation, foreign student, extra-time activities, humanization, Russian higher education.
Кочесокова Мадина Петровна

К.филол.н., дочент, ФГБОУ ВО «Кабардино-Балкарский государственный университет имени Х.М. Бербекова» madina_kochesokova@mail.ru

Абазова Людмила Мухамедовна

К.фрилол.н., дочент, ФГБОУ ВО «Кабардино-Балкарский государственный университет имени Х.М. Бербекова» abazova.ludmila@mail.ru

Джанхотова Зауризат Хасановна К.филол.н., дочент, ФГБОУ ВО «Кабардино-Балкарский государственный университет имени Х.М. Бербекова» djanchotova@mail.ru

Гутаева Жансурат Жуашовна К.филол.н., дочент, ФГБОУ ВО «Кабардино-Балкарский государственный университет имени Х.М. Бербекова» gutaevazhanna@mail.ru

Аннотация: (татья посвящена изучению внеучебной деятельности как механизма адаптации иностранных студентов в российских вузах. Автором доказана актуальность и значимость темы исследования. Необходимость организации внеучебной деятельности в образовательных организациях, где субъектами обучения являются иностранные студенты, доказывается через призму идеи гуманизации. Обосновывается тезис о том, что внеучебная деятельность, как одно из проявлений непрерывного образования, в рамках которого возможно создание гуманистически-ориентированной среды, является направлением способным сформировать и подготовить иностранного студента к дальнейшему развитию адаптивной компетенции, в т.Ч. в условиях будущей профессиональной деятельности.

Ключевые слова: адаптация, дезадаптация, иностранный студент, внеурочная деятельность, гуманизация, российское высшее образование.

Вопросам адаптации (академической, языковой, социально-бытовой, социально-психологической, социокультурной, дидактической и пр.), как в российской (К.А. Абульханова-Славская, В.И. Андреев, И.А. Зимняя, Е.Ф. Изотова, И.Л. Мушарапова, С.Ю. Родонова, А.И. Сурыгина, А.Г. Терещенко, И.В. Ширяева и др.), так и зарубежной науке (С. Бочнер, Э. Гидденс, Дж. Гюллахорн, В.Кастро, Р. Ламберт, Т. Лондаджим, Л. Фредлендер, Б. Хендриксон и др.) по сей день уделяется колоссальное внимание, разрабатываются актуальные методы и инструменты, которые кладутся в основу программ работы с иностранными студентами. Однако, важно обратить внимание на то, что некоторые из педагогических направлений, успешно имплементируемых в практику отечественных ВУЗов не освещаются наукой, или до сих пор мало разработаны. К ним следует отнести направление внеучебной деятельности; оно активно разрабатывается как одно из педагогических условий, способствующих успешности и результативности обучения студента 
- будущего специалиста (Е.В. Андреева, Г.В. Балахничева, М.В. Бирюкова, Р.В. Дружинина, А.В. Коломец, Н.А. Медведева, Т.В. Степура, А.Н. Чиж и пр.), однако, фундаментальных исследований, где объектом служила бы адаптация иностранных студентов, практически нет. Доказательством целесообразности разработки такого механизма, как внеучебная деятельность является то, что, как отметила Е.А. Набивачева, «дезадаптированная личность [иностранного студента] аккумулирует в себе определенные негативные социальные влияния, которые либо непосредственно исходят от среды, от ее ближайшего окружения, либо являются следствием нарушения действия механизмов ее социализации и адаптации» [8, с. 5].

В результате своего диссертационного исследования Е.А. Набивачева сделала вывод о том, что в целях профилактики данного негативного проявления необходимо создание гуманистически-ориентированной среды, «способствующей смягчению культурного шока, испытываемого иностранными студентами в чужой стране» $[8$, с. $5,11]$. Действительно, сегодня стал аксиомой постулат, в соответствии с которым без гуманистически ориентированной педагогики невозможно качественное, отвечающее требованиям времени, профессиональное образование. Как отмечает К.О. Чепеленко, в гуманизации образования заключены возможности «актуализации потенциала аналитико-критического конструктивного мышления, основы стимулирования таких универсальных ценностей, как нравственность, ответственность, уважение к труду, коллективизм, солидарность, патриотизм, формирующее образ индивидуума, соответствующего идее humanitas - идее, отличающей человека от всего живущего на земле» [10, с. 118]. В научной литературе [6] доказывается тот факт, что создание гуманистически-ориентированной среды возможно лишь в условиях обеспечения т.н. «lifewide learning» - «обучения шириной в жизнь», принципа, составляющего основу непрерывного образования. Гуманизация непрерывного образования, отмечает Н.Ю. Максимова, в первую очередь, «обеспечивают функцию культуры, обеспечивает целостность и непрерывность форм передачи социокультурного опыта» [7, с. 4], что, по общеизвестному мнению, является базисом эффективной адаптации иностранного студента $[3,5,12,13]$.

Одним из проявлений реальности непрерывного образования студенческой молодежи является внеучебная (профессиональная) деятельность. Анализ научных источников (Л.В. Алиева, Н.С. Бейлина, П.М. Васильев, Р.В. Дружинина, Т.Л. Иванайская, А.Б. Иванова, В.И. Кравчук, Е.М. Самохвалова, А.Н. Чиж, Н.И. Шульга и пр.) позволил нам дать следующее определение данной категории: форма неформального социального взаимодействия субъектов образовательного процесса в свободное от основных занятий время, способствующая профессиональному и личностному развитию студентов в органи- зованных ВУЗом условиях. Ценность данного механизма адаптации студентов с различным культурным опытом доказывается результатами зарубежных эмпирических исследований, например, американцами Дж. Кимом и М.Н. Бастедо; ученые выявили, что обучающиеся из разных штатов Америки, имеющие навыки общественной и социальной работы, легче адаптируются к новым условиям, быстрее входят в студенческий, а впоследствии и профессиональный коллектив, оттого уровень удовлетворенности местом обучения у них выше [14]. Другие исследователи - Р.А. Бакобан и С.А. Алираха (Саудовская Аравия) в результате опытно-экспериментальной работы со студентами Университета им. короля Абдул-Азиза, пришли к выводам о том, что внеучебная деятельность влияет также на успеваемость и мотивацию студентов [11], т.е. усиливают их академическую адаптацию. Одной из рекомендаций авторов является постоянное обновление и увеличение форм и видов внеучебной деятельности, а также разработка поощрительных мероприятий, стимулирующих студентов к участию в данном образовательном направлении. Интересные результаты представлены М. Ромбокасом: автор также доказал, что внеучебная деятельность позитивно влияет на успеваемость и мотивацию студентов, а также определил, что данный образовательный механизм способствует эффективному приспособлению обучающихся начальных курсов к новой среде, к жизни в университете и на кампусе. Кроме того, интерес представляет вывод автора о том, что существует непосредственная взаимосвязь между видом внеучебной деятельности, которой занимается студент, учебной дисциплиной, в которой он достигает наибольших успехов, и формирующимися у него личностными качествами [15]. То есть, у тех, кто, например, занимался вокалом, наиболее ярко выражено чувство ответственности и повышена самооценка, а у участников театральных кружков - более развиты самоорганизация и дисциплинированность.

Приведенные позиции позволят заключить, что внеурочная деятельность, особенно дифференцированная под потребности и интересы студентов является действенным механизмом формирования так называемой адаптивной компетенции, т.е. совокупности знаний, умений, навыков, представлений и алгоритмов действий, системы ценностей и отношений $[2,9]$, которые актуализированы в процессе социокультурной (приоритет), академической, социально-психологической, языковой и иных форм адаптации на всех этапах образовательной деятельности в ВУЗе. Подтверждая эмпирически данный тезис Г.П. Иванова, О.К. Логвинова, Н.В. Сомова [4, 9] и др. акцентируют внимание на том, что в условиях организации внеурочной деятельности в российских ВУЗах, обязательно должны иметь место, во-первых, психолого-педагогическое сопровождения (подготовка иностранных обучающихся к межкультурному взаимодействию в новой социокультурной среде посредством специаль- 
но разработанных форм и методов, а также технологий взаимодействия педагога и студента: различные виды тренингов, ориентирование, «культурный ассимилятор» и пр.), и, во-вторых, научно-методическое сопровождение (разработка и реализация программ внеурочной деятельности - семинары, тренинги, клубы и пр.). На наш взгляд, это верно и важно, однако эффективной адапта- ция иностранных студентов будет лишь при условии оптимальной организации соответствующего механизма во всей образовательной середе, так как внеурочная деятельность, как отмечают Т.Ю. Ломакина и Д.А. Писаренко [6], будучи неформальным образованием, способно компенсировать «пробелы» формального образования, но не заменить его.

\section{ЛИТЕРАТУРА}

1. Паспорт национального проекта "Образование" (утв. президиумом Совета при Президенте РФ по стратегическому развитию и национальным проектам, протокол от 24.12.2018 N 16) // СПС «ГАРАНТ».

2. Андреева Е.В. Качество профессиональной подготовки студентов в социальной системе внеучебной деятельности: монография; Министерство науки и высшего образования Российской Федерации, Северо-Восточный федеральный университет имени М.К. Аммосова. - Якутск: ИД СВФУ, 2019. - 127 с.

3. Береговая 0.А., Лопатина С.С., Отургашева Н.В. Барьеры социокультурной адаптации иностранных студентов в российских вузах // Перспективы науки и образования. 2019. № 2 (38). С. 108-118

4. Иванова Г.П., Логвинова О.К. Внеучебная деятельность в современном российском университете: взгляд студентов и преподавателей // Евразийский журнал математики, естествознания и технологического образования. 2017. № 13 (11). С. 7431-7439.

5. Лебедев А.Ю., Дубровин Г.М., Павлов В.К. Особенности профессиональной ориентации и проблемы социокультурной, педагогической адаптации студентов международного факультета медицинского университета // Коллекция гуманитарных исследований. 2020. №2 (23). С. 41-45

6. Ломакина Т.Ю., Писаренко Д.А. Внеучебная деятельность студентов высшей школы в контексте реализации концепции непрерывного образования // Отечественная и зарубежная педагогика. 2020. №1 (65). С. 20-32

7. Максимова Н.Ю. Гуманизация образования как социокультурный процесс: Философские аспекты: автореф. дис. .... канд. философ. наук: 24.00 .01 / Моск. гос. ун-т культуры и искусств. - Москва, 2003. - 18 с.

8. Набивачева Е.А. Профилактика дезадаптации иностранных студентов в образовательном процессе российского вуза: автореф. дис. ... канд. пед. наук: 13.00.01 / Набивачева Екатерина Александровна; [Место защиты: Дальневост. гос. гуманитар. ун-т]. - Хабаровск, 2007. - 21 с.

9. Сомова Н.В. Формирование социально-адаптивной компетентности иностранных студентов на этапе предвузовской подготовки: автореф. дис. ... канд. пед. наук: 13.00.08 / Сомова Наталья Владимировна; [Место защиты: Ленингр. гос. обл. ун-т им. А.С. Пушкина]. - Санкт-Петербург, 2015. - 23 с.

10. Чепеленко К.0. Гуманизация в пространстве непрерывного образования // Изв. Сарат. ун-та Нов. сер. Сер. Философия. Психология. Педагогика. 2017. C. $117-120$.

11. Bakoban, R.A., Aljarallah, S.A. Extracurricular Activities and Their Effect on the Student's Grade Point Average: Statistical Study // Educational Research and Reviews. 2015. Vol 10. № 20. P. 2737-2744

12. Castro V.S. Acculturation and psychological adaptation. Westport, CT: Greenwood Press, 2003. - 215 p

13. Friedlander L., Reid G., Shupak N., Cribbie R. Social support, self-esteem, and stress as predictors of adjustment to university among first-year undergraduates // Journal of College Student Development. 2007. Vol. 48(3). pp. 259-274

14. Kim J., Bastedo M. Athletics, clubs, or music? The influence of college extracurricular activities on job prestige and satisfaction // Journal of Education and Work. 2016. 22 p. DOI: 10.1080/13639080.2016.1165341

15. Rombokas M. High School Extracurricular Activities \& College Grades // Paper presented at the Southeastern Conference of Counseling Center Personnel and the Tennessee Counseling Association Convention. 1995. - 36 p.

( К Кочесокова Мадина Петровна (madina_kochesokova@mail.ru),Абазова Людмила Мухамедовна (abazova.ludmila@mail.ru)، Джанхотова Зауризат Хасановна (djanchotova@mail.ru), Гутаева Жансурат Жуашовна (gutaevazhanna@mail.ru).

Журнал «Современная наука: актуальные проблемы теории и практики» 